\title{
Peramalan Indeks Harga Prulink Rupiah Equity Fund Dengan Metode Exponential Moving Average
}

\author{
Agung Mahadewa*1, Made Gitra Aryawan ${ }^{2}$, Pradita Eko Prasetyo Utomo ${ }^{3}$ \\ ${ }^{1}$ Fakultas Ekonomika dan Bisnis, Megister Manajemen, Universitas Gadjah Mada, Yogyakarta \\ ${ }^{2}$ Fakultas Ekonomi Pembangunan, Universitas Tabanan, Bali \\ ${ }^{3}$ Program Studi Sistem Informasi, Universitas Jambi, Jambi \\ e-mail: ${ }^{* 1}$ i.pt.a@mail.ugm.ac.id, ${ }^{2}$ made.gitra@ @mail.com, ${ }^{3}$ pradita.eko@ unja.ac.id
}

\begin{abstract}
Abstrak
Salah satu perusahaan asuransi jiwa yang memiliki produk investasi yang ditambahkan dengan produk proteksi, Dari beragam pilihan produk investasi yang ditawarkan, produk PRUlink Rupiah Equity Fund adalah yang paling diminati, produk ini juga memiliki fluktuasi yang tinggi dibandingkan dengan produk lainnya. Karena itu seorang nasabah yang juga menjadi investor dalam hal ini, sering merasa dirugikan oleh pihak asuransi pada saat melakukan penarikan dana yang dimilikinya, hal tersebut disebabkan oleh kurangnya pengetahuan untuk mengetahui indeks harga periode selanjutnya.

Dugaan yang tepat adalah informasi utama yang dibutuhkan oleh investor dalam menentukan strategi selanjutnya dalam berinvestasi, Salah satunya adalah metode Exponential Moving Average. Metode ini merupakan metode deret waktu yang digunakan untuk memprediksi masa depan dengan menggunakan data historis. Pemberian bobot melibatkan periode, jadi semakin panjang periode yang kita gunakan maka semakin kecil pembobotan nilai terakhir yang kita gunakan.

Dengan melimpahnya data yang ada maka dibangunnya suatu sistem yang memanfaatkan data masa lalu, dengan kata lain model deret waktu mencoba menggunakan deret waktu masa lalu untuk meramalkan, nantinya sistem akan berguna untuk membantu investor dalam meramalkan dugaan dari besarnya nilai Equity Fund di waktu yang akan datang sehingga dapat menentukan strategi yang tepat untuk investasi
\end{abstract}

Kata kunci-Equity Fund, Exponential Moving Average, Investasi

\begin{abstract}
Company that has the added investment products with protection products, from a variety of investment products offered, product PRUlink Rupiah Equity Fund is the most desirable, the product has a high volatility compared to other products. Because it is a customer who is also an investor in this case, often feel disadvantaged by the insurer at the time of withdrawal own funds, it is caused by a lack of knowledge to know the price index next period

Alleged right is the main information needed by investors to determine the next strategy in investing, One is the method of Exponential Moving Average. This method is a method of time series are used to predict the future by using historical data. Assigning weights to involve periods, so the longer the period that we use, the smaller the final value weighting we use

With the abundance of available data, the construction of a system that utilizes past data, in other words, try using a time series model time series of the past to predict, the system will be useful to assist investors in predicting the allegations of the value of equity funds in the future so as to determine the appropriate strategy for investment.
\end{abstract}

Keywords - Equity Fund, Exponential Moving Average, Investment

Received December $6^{\text {th }}, 2018 ;$ Revised December 16 ${ }^{\text {th }}, 2018$; Accepted December $28^{\text {th }}$, 2018 


\section{PENDAHULUAN}

Pada saat ini peran pasar modal dalam perekonomian Indonesia mulai melembaga. Pembelian saham menjadi salah satu pilihan modal bagi investor, selain bentuk modal lainnya seperti uang, tanah, dan emas. Di pasar modal inilah setiap investor dapat memilih berbagai investasi yang ada, dimana setiap investasi memiliki karakteristik tersendiri dalam hal tingkat pengembalian (return) dan risiko (risk). Dengan tingkat volatilitas yang tinggi, sedikit investor yang mengetahui apakah harga saham yang dimilikinya akan naik dengan mendulang keuntungan yang besar, atau justru sebaliknya mengakibatkan uang yang dimiliki semakin menipis dan menuai kerugian [1].

Indeks harga saham adalah suatu indikator yang menunjukkan pergerakan harga saham. Indeks berfungsi sebagai indikator trend pasar yang mampu menggambarkan kondisi pasar pada suatu waktu. Pergerakan indeks juga menjadi indikator penting bagi para investor dalam memberikan suatu keputusan untuk menjual, menahan, atau membeli saham. Salah satu alternatif jenis investasi yang dipilih oleh investor adalah berinvestasi di Reksa Dana yaitu dengan membeli unit penyertaan. Seperti jenis investasi lainnya, Reksa Dana juga mengalami ketidakpastian. Hal ini disebabkan karena saham berhubungan dengan keadaan yang terjadi, seperti perekonomian, politik, industri dan keadaan perusahaan. Dengan semakin banyaknya jumlah investor memaksa perusahaan asuransi untuk menawarkan produk-produk yang lebih kompetitif. Ketika perusahaan asuransi mulai menyediakan produk investasi, perusahaan tersebut tidak hanya bersaing dengan perusahaan asuransi jiwa yang lain, tetapi mereka juga bersaing dengan perusahaan keuangan yang menyediakan produk-produk investasi.

Perusahaan yang bergerak dalam bidang asuransi jiwa yang dikaitkan dengan investasi. Istilah lain yang sering digunakan adalah unit link. Dari sisi investasi, PT. Prudential Life Assurance menawarkan beberapa produk investasi pilihan bagi investor. Dari beragam pilihan produk investasi yang ditawarkan, produk yang akan dibahas dalam penelitian ini adalah PRUlink Rupiah Equity Fund. Selain karena produk ini adalah yang paling diminati, produk ini juga memiliki fluktuasi yang tinggi dibandingkan dengan produk lainnya. Karena itu seorang nasabah yang juga menjadi investor dalam hal ini, sering merasa dirugikan oleh pihak asuransi pada saat melakukan penarikan (withdrawal) dana yang dimilikinya, hal tersebut disebabkan oleh kurangnya pengetahuan untuk mengetahui indeks harga PRUlink Rupiah Equity Fund periode selanjutnya. Dugaan yang tepat adalah informasi utama yang dibutuhkan oleh investor dalam menentukan strategi selanjutnya dalam berinvestasi, Ada beberapa metode peramalan yang dapat digunakan untuk menyelesaikan masalah perusahaan salah satunya adalah metode neural network [2][3] namun memiliki kekurangan dari segi waktu peramalan [4]. Metode Exponential Moving Average merupakan salah satu metode yang dapat dengan cepat untuk proses peramalan. Metode ini merupakan metode deret waktu yang digunakan untuk memprediksi masa depan dengan menggunakan data historis [5]. Dengan kata lain, model deret waktu mencoba melihat apa yang terjadi pada masa kurun waktu tertentu dan menggunakan deret waktu masa lalu untuk meramalkan masa yang akan datang [6] [7].

Berdasarkan permasalahan yang diuraikan oleh penulis, diperlukan suatu sistem yang dapat membantu nasabah dan investor dalam meramalkan dugaan yang tepat dari besarnya nilai PRUlink Rupiah Equity Fund di waktu-waktu yang akan datang sehingga dapat menentukan strategi yang tepat untuk investasi. Berdasarkan latar belakang diatas, Maka judul yang diambil oleh penulis adalah "Peramalan Indeks Harga PRUlink Rupiah Equity Fund dengan Metode Exponential Moving Average".

JSIKTI Vol. 1, No. 2, December 2018: $87-96$ 


\section{METODE PENELITIAN}

\subsection{State Of The Arts}

Penerapan Model ARIMA Untuk Memprediksi Harga Saham PT. Telkom Tbk, untuk mengetahui karakteristik data harga saham harian PT. Telkom, Tbk, membuat model dan melakukan prediksi harga saham PT. Telkom, Tbk bulan Mei sampai Juni tahun 2011. Data yang digunakan adalah data sekunder yang diambil dari website perusahaan PT. Telkom, Tbk sejak Januari 2010 sampai 30 Maret 2011 untuk memprediksi harga saham Mei sampai Juni 2011. Kesimpulan pada penelitian ini ialah metode ARIMA dapat memberikan solusi kepada pihak manajemen untuk meramalkan harga saham PT.Telkom Tbk pada periode tertentu. Hasil peramalan tersebut dapat digunakan sebagai acuan didalam pengambilan keputusan [8].

Penelitian serupa juga telah dilakukan oleh [9]. Dalam penelitiannya berjudul Peramalan Cuaca Kota Surabaya Tahun 2011 Mengunakan Metode Moving Average, kesimpulan yang didapat ialah peramalan ini juga kadang tepat dengan yang ada dan kadang pula salah sehingga kita hanya menggunakan perkiraan dalam suatu peramalan ini. Tapi dapat dipastikan lebih dari 50\% dapat diakatan kebenarannya tapi kita juga tidak boleh terlalu, jadi kita hanya dapat berusaha dengan menggunakan aplikasi.

Perbedaan penelitian sebelumnya dengan penelitian ini yang berjudul Peramalan Indeks Harga Prulink Rupiah Equity Fund dengan Metode Exponential Moving Average di PT. Prudential Life Assurance yaitu pada penelitian ini user dapat memilih jumlah periode kebelakang secara manual serta menampilkan secara otomatis nilai peramalan dan nilai error yang dimiliki oleh periode tersebut dan akan muncul grafik perbandingan antara harga sebenarnya dengan harga peramalan

\section{2 Peramalan}

Peramalan adalah kegiatan memperkirakan apa yang terjadi pada waktu yang akan datang sedangkan rencana merupakan penentuan apa yang akan dilakukan pada waktuyang akan datang. Peramalan menjadi sangat penting karena penyusunan suatu rencana diantaranya didasarkan pada suatu proyeksi atau ramalan[10]-[12]. Pada hakekatnya banyak keputusan penting yang dilakukan secara pribadi, instansi, maupun perusahaan kepada kejadian-kejadian dimasa yang akan mendatang sehingga memerlukanramalan tentang keadaan lingkungan masa depan tersebut. meningkatkan keberhasilan pembangunan untuk mencapai tujuannya [13]-[15].

\subsubsection{Kegunaan dan Peran Peramalan}

Kegunaan dari peramalan terlihat pada saat pengambilan keputusan. Setiap orang selalu dihadapkan pada masalah pengambilan keputusan. Keputusan yang baik adalah keputusan yang didasarkan pertimbangan apa yang akan terjadi pada waktu keputusan itu dilaksanakan. Kurang tepat ramalan yang kita susun atau yang kita buat maka kurang baiklah keputusan yang kita ambil. Walaupun demikian perlu disadari bahwa suatu ramalan adalah tetap ramalan, dimana selalu ada unsur kesalahan. Sehingga yang paling diperhatikan adalah usaha untuk memperkecil kemungkinan kesalahannya [10]

\subsubsection{Jenis-Jenis Peramalan}

Menurut [10] Berdasarkan sifat ramalan yang telah disusun, maka peramalan dapat dibedakan atas dua macam, yaitu

1. Peramalan Kualitatif adalah peramalan yang didasarkan atas data kualitatif pada masa lalu. Hasil peramalan yang dibuat sangat tergantung pada orang yang menyusunnya.

2. Peramalan Kuantitatif adalah peramalan yang didasarkan atas data kuantitatif pada masa lalu. Hasil peramalan yang dibuat sangat tergantung pada metode yang dipergunakan dalam peramalan tersebut.

Peramalan Kuantitatif dapat diterapkan bila terdapat kondisi berikut 
1. Tersedia informasi (data) tentang masa lalu.

2. Informasi (data) dapat dikuantitatifkan dalam bentuk data numerik.

3. Dapat diasumsikan bahwa beberapa aspek pola masa lalu akan terus berlanjutpasa masa yang akan datang .

Baik tidaknya metode yang digunakan dapat dilihat dari perbedaan atau penyimpangan antara hasil ramalan dengan kenyataan yang terjadi. Semakin kecil penyimpangan antara hasil ramalan dengan kenyataan yang terjadi, maka semakin baik pula metode yang digunakan.

\subsubsection{Pengertian dan Kegunaan Metode Peramalan}

Metode peramalan adalah cara memperkirakan secara kuantitatif apa yang akan terjadi pada masa depan, berdasarkan data yang relevan pada masa lalu. Oleh karena metode peramalan didasarkan atas data yang relevan pada masa lalu, maka metode peramalan ini dipergunakan dalam peramalan yang obyektif.

Sebagaimana diketahui bahwa metode peramalan merupakan cara berfikir yang sistematis dan pragmatis atas pemecahan suatu masalah. Disamping itu metode peramalan juga memberikan urutan pengerjaan dan pemecahan atas pendekatan suatu masalah dalam peramalan. Selain itu, metode peramalan memberikan cara pengerjaan yang teratur dan terarah, sehingga dengan demikian dapat dimungkinkannya penggunaan tekni-teknik penganalisaan yang lebih maju. Dengan penggunaan teknik-teknik tersebut, maka diharapkan dapat memberikan kepercayaan atau keyakinan yang lebih besar, karena dapat diuji dan dibuktikan penyimpangan (deviasi) yang terjadi secara ilmiah. Dari uraian diatas, dapat disimpulkan bahwa metode peramalan sangat berguna, karena akan membantu dalam mengadakan pendekatan analisis terhadap tingkah laku atau pola dari data yang lalu. Sehingga dapat memberikan cara pemikiran, pengajaran dan pemecahan yang sistematis dan pragmatis, serta memberikan tingkat keyakinan yang lebih besar atas ketetapan hasil ramalan yang dibuat [10]

\subsubsection{Jenis-Jenis Metode Peramalan}

Sofjan (1984) mengutarakan bahwa metode peramalan yang digunakan atas penggunaan analisa hubungan antar variabel yang diperkirakan dengan variabel waktu merupakan deret berkala (Time Series). Metode peramalan yang termasuk pada jenis ini yaitu :

1. Metode Pemulusan (Smoothing)

2. Metode Box Jenkins

3. Metode Proyeksi Trend dengan regresi

Metode peramalan yang didasarkan atas penggunaan analisis pola hubungan antar variabel yang akan diperkirakan dengan variabel lain yang mempengaruhinya, yang bukan waktunya disebut Metode Korelasi atau sebab akibat (metode causal). Metode yang termasuk dalam jenis ini adalah:

1. Metode Regresi dan Korelasi

2. Metode Ekonometri

3. Metode Input Output

\subsubsection{Pasar Modal}

Pasar modal adalah pasar dari berbagai instrumen keuangan (sekuritas) jangka panjang yang dapat diperjualbelikan, baik dalam bentuk hutang (obligasi) maupun modal sendiri (saham) yang diterbitkan pemerintah atau perusahaanswasta. Pada dasarnya fungsi pasar modal sebagai wahana demokratisasi pemilikan saham yang ditunjukkan dengan semakin banyaknya institusi dan individu yang memiliki saham perusahaan yang telah go public.

Sebagaimana telah disinggung sebelumnya, pasar modal mempunyai peranan penting dalam mobilisasi dana untuk menunjang pembangunan nasional. Akses dana dari pasar modal telah mengundang banyak perusahaan nasional maupun patungan untuk menyerap dana 
masyarakat tersebut dengan tujuan yang beragam Namun, sasaran utamanya adalah meningkatkan produktivitas kerja

melalui ekspansi usaha dan/atau mengadakan pembenahan struktur modal untuk meningkatkan daya saing perusahaan. Instrumen-instrumen pasar modal Indonesia yang memungkinkan mobilisasi dana masih relatif terbatas jika dibandingkan dengan bursa-bursa dunia yang sudah mapan [16]

\section{3 Model Peramalan Moving Average}

Merupakan indikator yang paling sering digunakan dan paling standar. Jika di Indonesiakan artinya rata-rata bergerak. Moving average sendiri dikatakan sederhana karena pada dasarnya metode ini hanyalah pengembangan dari metode rata-rata. Moving average memiliki tiga varian yang berbeda yaitu Simple Moving Average, Weighted Moving Average, dan Exponential Moving Average, masing-masing merupakan metode rata-rata bergerak, hanya saja cara merata-ratakanya yang berbeda satu sama lain. Karakteristik Khusus Rata-rata Bergerak (Moving Average), Metode moving average memiliki karakteristik khusus [17].

1. Untuk menentukan ramalan pada periode yang akan datang memerlukan data historis selam jangka waktu tertentu.

2. Semakin panjang jangka waktu rata-rata bergerak (moving average), efek pelicinan semakin terlihat dalam ramalan atau menghasilkan rata-rata bergerak (moving average) yang semakin halus. Artinya pada rata-rata bergerak (moving average) yang jangka waktunya lebih panjang, perbedaan ramalan terkecil dengan ramalan terbesar menjadi lebih kecil.

\subsubsection{Metode Exponential Moving Average (EMA)}

Menurut Indriyo (2000), EMA atau yang dikenal Exponential Moving Average merupakan penyempurnaan dari metode Single Moving Average (SMA). Pemberian bobot pada EMA melibatkan periode, jadi semakin panjang periode yang kita gunakan maka semakin kecil pembobotan nilai terakhir yang kita gunakan. Secara matematis EMA ditulis dalam bentuk sebagai berikut :

$$
E M A=\left(\frac{2}{\text { periode }+1} x(\text { nilaisekarang }- \text { nilaisebelumEMA })+\text { nilaisebelumEMA }\right)
$$

\subsubsection{Menghitung Kesalahan Peramalan}

Hasil proyeksi yang akurat adalah ramalan yang bisa meminimalkan kesalahan meramal. Besarnya kesalahan meramal dihitung dengan mengurangi data riil dengan besarnya ramalan (Indriyo, 2000).

$\begin{array}{ll}\text { Rumus } & : \text { Error }(\mathrm{E})=\mathrm{X}_{\mathrm{t}}-\mathrm{F}_{\mathrm{t}} \\ \text { Keterangan } & \\ \mathrm{X}_{\mathrm{t}} & : \text { data riil periode }-\mathrm{t} \\ \mathrm{F}_{\mathrm{t}} & : \text { ramalan periode ke }-\mathrm{t}\end{array}$

Dalam menghitung kesalahan ramalan digunakan.

1. Mean Absolute Error

Mean Absolute Error adalah rata-rata absolute dari kesalahan meramal, tanpa menghiraukan tanda positif maupun negatif.

$$
M A E=\frac{\sum \mid X_{t}-F_{t}}{n}
$$

2. Mean Squared Error

Mean Squared Error adalah kuadrat rata-rata kesalahan meramal. 


$$
M S E=\frac{\sum\left(X_{t}-F_{t}\right)^{2}}{n}
$$

\section{4 Activity Diagram Peramalan Rupiah Equity Fund}

Pada Activity Diagram ini user sebagai aktor dapat melakukan peramalan rupiah equity fund. Prosesnya dapat di lihat pada Gambar 1. Activity Diagram Peramalan Rupiah Equity Fund. Gambar 1 menjelaskan alur kerja pada data user, admin membuka halaman peramalan kemudian sistem akan menampilkan form peramalan, dimana pada form tersebut user melakukan peramalan rupiah equity fund.

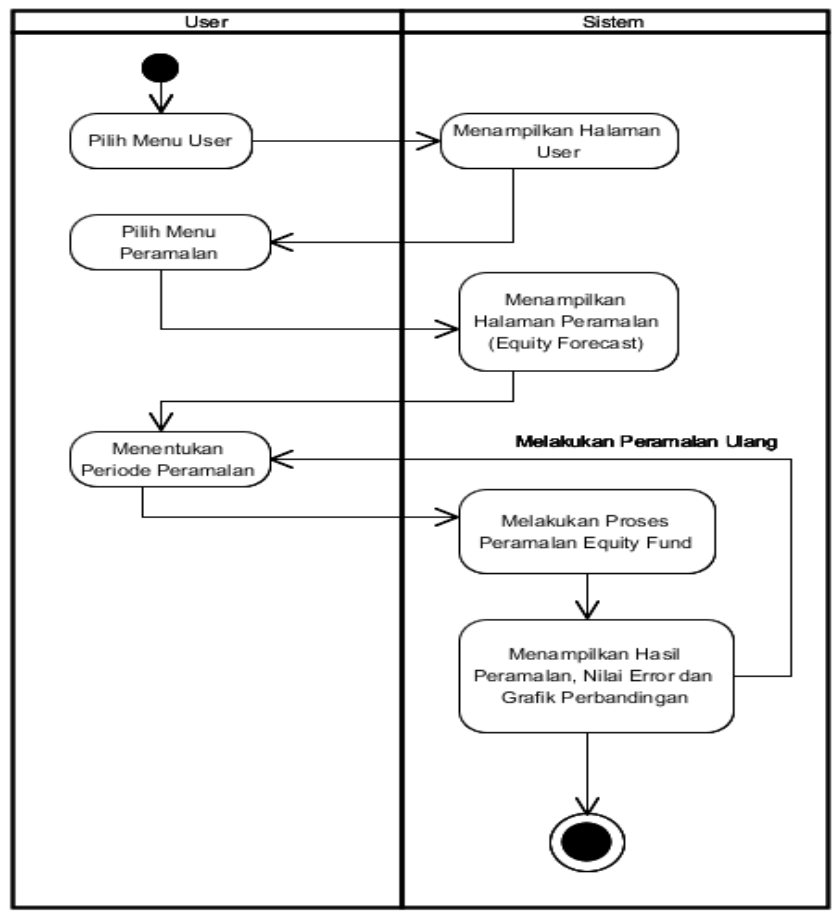

Gambar 1 Ilustrasi Citra Digital

\section{5 Perhitungan Metode Exponential Moving Average}

Penggunaan metode Exponential Moving Average dalam Peramalan Rupiah Equity Fund ialah dalam hal menghitung nilai periode berikutnya, dimana akan lebih bermanfaat jika nasabah yang menjadi investor mengetahui gambaran nilai periode berikutnya. Dengan Exponential Moving Average, investor dapat merancang atau menyususn rencana setelah mengetahui gambaran nilai periode berikutnya.

Untuk melakukan perhitungan diambil sampel 10 record pada Data Indeks Harga PRUlink Rupiah Equity Fund Januari 2013 di PT. Prudential Life Assurance sebagai berikut:

Berikut adalah Hasil Peramalan Indeks Rupiah Equity Fund dengan metode EMA dapat dilihat pada Tabel 1.

Nilai Previous EMA diperoleh dari,

Rumus :

Previous EMA $=($ Harga $1+2+3+4+5+6) /$ periode

$=((12,978+12,978+12,978+13,018+13,018+13,018) / 6)$

$=12,998$

Berikut adalah Perhitungan Metode EMA 6 periode:

Tabel 1 Hasil Perhitungan Metode EMA

JSIKTI Vol. 1, No. 2, December 2018 : 87 - 96 


\begin{tabular}{|c|c|c|c|c|}
\hline NO & \multicolumn{1}{c}{ Tanggal } & Harga & Previous EMA & EMA \\
\hline 1 & 1-Jan-13 & 12,978 & & \\
\hline 2 & 2-Jan-13 & 12,978 & & \\
\hline 3 & 3-Jan-13 & 12,978 & & \\
\hline 4 & 4-Jan-13 & 13,018 & & \\
\hline 5 & 5-Jan-13 & 13,018 & & \\
\hline 6 & 6-Jan-13 & 13,018 & 12,998 & 13,025 \\
\hline 7 & 7-Jan-13 & 12,978 & 12,998 & 12,971 \\
\hline 8 & 8-Jan-13 & 12,991 & 13,000 & 12,988 \\
\hline 9 & 9-Jan-13 & 12,849 & 12,979 & 12,806 \\
\hline 10 & 10-Jan-13 & 12,712 & 12,928 & 12,640 \\
\hline
\end{tabular}

Sedangkan Nilai EMA diperoleh dari,

Rumus :

EMA $=\left(\frac{2}{\text { periode }+1} x\right.$ (nilaisekarang - nilaisebelumEMA $)+$ nilaisebelumEMA $)$

$\mathrm{EMA}=(((2 / 6+1) *(13,018-12,998)+12,998))$

$=13,025$

Perhitungan terus dilakukan seperti cara diatas untuk memperoleh nilai EMA berikutnya.

\section{6 Ukuran Akurasi Peramalan}

Model-model peramalan yang dilakukan kemudian divalidasi menggunakan sejumlah indikator. Dari bermacam-macam Indikator yang ada saya menggunakan rata-rata kuadrat terkecil (Mean Square Error).

Mean Squared Error (MSE) adalah metode lain untuk mengevaluasi metode peramalan. Masing-masing kesalahan atau sisa dikuadratkan. Kemudian dijumlahkan dan ditambahkan dengan jumlah observasi. Pendekatan ini mengatur kesalahan peramalan yang besar karena kesalahan-kesalahan itu dikuadratkan. Metode itu menghasilkan kesalahan-kesalahan sedang yang kemungkinan lebih baik untuk kesalahan kecil, tetapi kadang menghasilkan perbedaan yang besar.

Tabel 2 Perhitungan Untuk Metode Evaluasi Peramalan

\begin{tabular}{|c|c|c|c|c|c|c|c|}
\hline NO & \multicolumn{1}{c}{$\begin{array}{c}\text { Tanggal } \\
\mathrm{t}\end{array}$} & \multicolumn{2}{c}{$\begin{array}{c}\text { Harga } \\
\mathrm{Y}_{\mathrm{t}}\end{array}$} & \multicolumn{2}{c|}{$\begin{array}{c}\text { Previous } \\
\text { EMA }\end{array}$} & $\begin{array}{c}\text { EMA } \\
\mathbf{Y}_{\mathrm{t}}\end{array}$ & \multicolumn{2}{c|}{$\begin{array}{c}\text { Error } \\
\mathrm{e}_{\mathrm{t}}\end{array}$} & $\left|\mathrm{e}_{\mathrm{t}}\right|$ & $\mathrm{e}_{\mathrm{t}}{ }^{2}$ \\
\hline 1 & 1-Jan-13 & 12,978 & & & & & \\
\hline 2 & 2-Jan-13 & 12,978 & & & & & \\
\hline 3 & 3-Jan-13 & 12,978 & & & & & \\
\hline 4 & 4-Jan-13 & 13,018 & & & & & \\
\hline 5 & 5-Jan-13 & 13,018 & & & & & \\
\hline 6 & 6-Jan-13 & 13,018 & 12,998 & 13,025 & -7 & 7 & 49 \\
\hline 7 & 7-Jan-13 & 12,978 & 12,998 & 12,971 & 7 & 7 & 49 \\
\hline 8 & 8-Jan-13 & 12,991 & 13,000 & 12,988 & 3 & 3 & 9 \\
\hline 9 & 9-Jan-13 & 12,849 & 12,979 & 12,806 & 43 & 43 & 1,849 \\
\hline 10 & 10-Jan-13 & 12,712 & 12,928 & 12,640 & 72 & 72 & 5,184 \\
\hline & Total & 129,518 & 64,903 & 64,801 & 118 & 132 & 7,140 \\
\hline
\end{tabular}

Perhitungan MSE sebagai berikut,

$\operatorname{MSE}=\left((13,018-13,025)^{2} / 6\right)=8,166667$

\section{7 Rancangan Halaman Forecasting}

Gambar 2 adalah rancangan halaman forecasting, pada halaman ini terdapat menu forecasting untuk meramalkan nilai equity periode berikutnya, dan nanti secara otomatis grafik perbandingan akan muncul. 


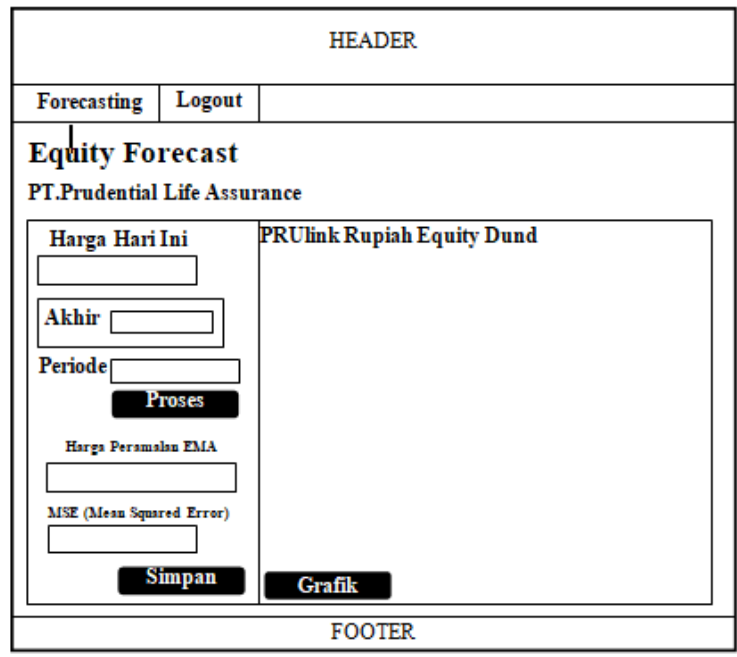

Gambar 2 Rancangan Halaman Forecasting

\section{HASIL DAN PEMBAHASAN}

Perancangan terhadap aplikasi, dilakukan langkah implementasi dan pengujian dari aplikasi yang telah dibuat. Implementasi merupakan tahapan yang dilakukan setelah penulisan kode program dan akan mengubah bentuk dari analisis maupun perancangan menjadi bentuk bahasa pemrograman. Setelah tahap implementasi, dilakukan pengujian terhadap aplikasi yang dibuat.

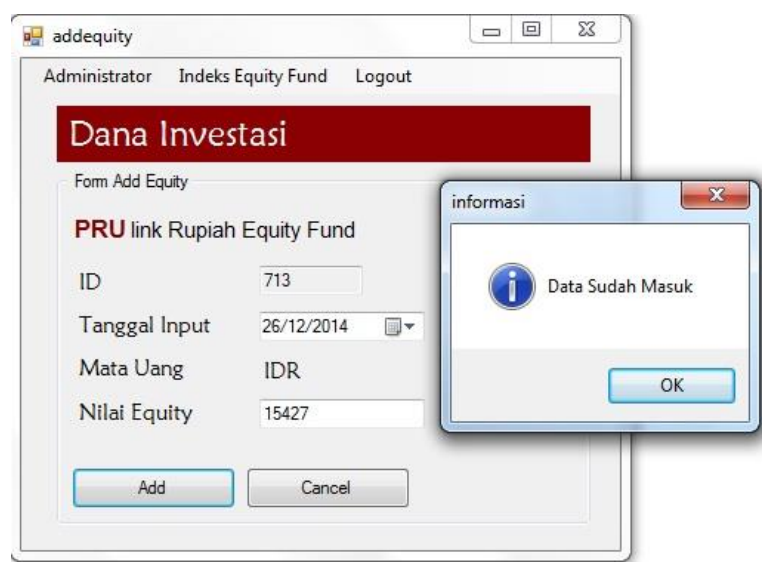

Gambar 3 Form Add equaty

Implementasi Aplikasi Sistem Peramalan Indeks Harga PRUlink Rupiah Equity Fund dengan Metode Exponential Moving Average di PT. Prudential Life Assurance membutuhkan sebuah perangkat pendukung, yaitu perangkat lunak dan perangkat keras, minimal harus dipenuhi sehingga aplikasi ini dapat berjalan dengan baik.Berikut adalah daftar kebutuhan perangkat lunak dan perangkat keras.

\subsection{Tampilan Form add equity}

Form add equity pada Gambar 3. ini berfungsi untuk menambahkan nilai equity setiap harinya, seperti form add admin, pada form ini, kolom id akan dibuat otomatis. Setelah admin menginputkan tanggal, dan nilai equity maka nilai equity yang baru sudah berhasil diinputkan. Setelah pada Gambar 3. nilai equity diinputkan maka hasilnya akan ditampilkan pada form view equity pada Gambar 4. 


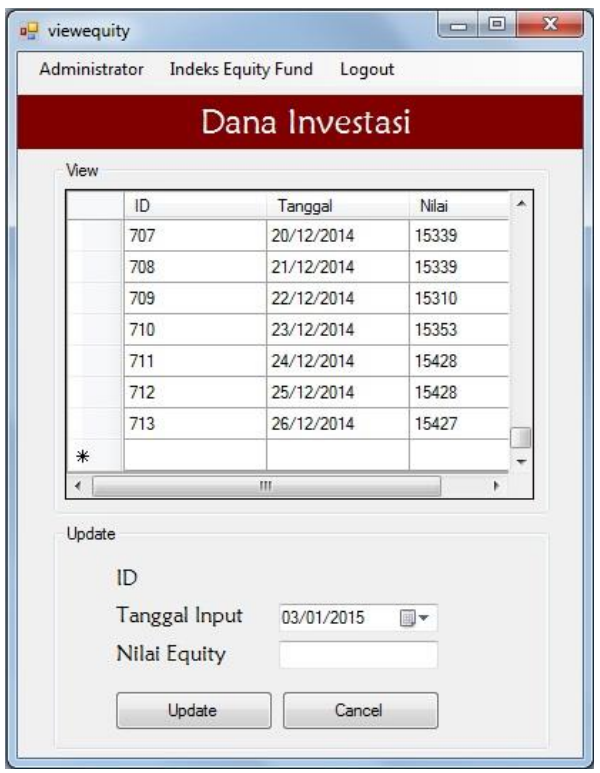

Gambar 4 Form view equaty

\subsection{Form Forecasting}

Form pada Gambar 5 ini adalah form utama yang berguna untuk membantu para user untuk memberikan prediksi peramalan nilai equity periode berikutnya. Tampilan formnya ditunjukan pada Gambar 5. Didalam form ini terdapat kolom harga equity hari ini yang otomatis terisi dan berubah setiap harinya sesuai dengan harga equity dari PT.Prudential Life Assurance pusat Jakarta, selain itu terdapat tanggal awal dan akhir, dan setelah itu ada combo untuk memilih periode data peramalan. Jika semua sudah dipilih makan tombol proses akan berguna untuk menampilkan hasil prediksi harga peramalan dari metode Exponential Moving Average dan juga akan menampilkan nilai selisih atau disebut nilai error dengan menggunakan metode MSE (Mean Squared Error). Tombol grafik nantinya berfungsi untuk menampilkan grafik dari kinerja niai equity fund.

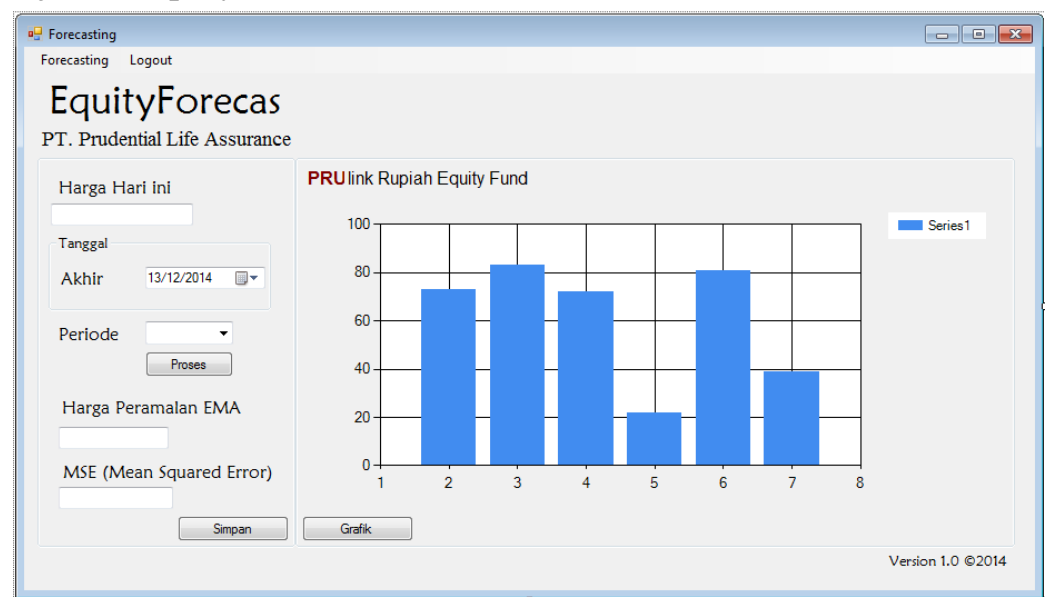

Gambar 5 Form Forecasting

\section{KESIMPULAN}

Hasil dari penelitian, mulai dari tahapan awal yaitu mulai mengumpulkan data dan kebutuhan (requirement), analisis sistem yang akan dibuat, perancangan sistem dengan Unified Modeling Language (UML), membangun sistem dengan VB.NET 2010 dan DBMS Microsoft Access, serta mengimplementasikannya, maka dapat ditarik kesimpulan Sistem Informasi Peramalan pada PT. Prudential Life Assurance dapat membantu memudahkan nasabah dalam 
menentukan strategi yang tepat untuk investasi karena sistem dapat meramalkan dugaan dari besarnya indeks harga Equity Fund periode berikutnya. Aplikasi ini bisa menjadi alat bantu dalam melihat perbandingan antara harga aktual dengan peramalan. Dari hasil pengujian yang dilakukan, perhitungan dengan metode exponential moving average dengan data latih yang digunakan periode Januari 2013 sampai dengan Juni 2014 dimana terdapat data sebanyak 534 record, periode yang digunakan sebanyak 31 periode, dari periode tersebut, periode ke-31 lah yang memiliki nilai peramalan yang mendekati dengan nilai aktual, dan memiliki nilai error terkecil.

\section{DAFTAR PUSTAKA}

[1] A. Mauko, B. Muslimin, and P. Sugiartawan, "Sistem Pendukung Keputusan Kelompok Dalam Pemilihan Saham Indeks LQ 45 Menggunakan Metode," J. Sist. Inf. dan Komput. Terap. Indones., vol. 1, no. 1, pp. 25-34, 2018.

[2] P. Sugiartawan, R. Pulungan, and A. K. Sari, "Prediction by a Hybrid of Wavelet Transform and Long-Short-Term-Memory Neural Network," Int. J. Adv. Comput. Sci. Appl., vol. 8, no. 2, pp. 326-332, 2017.

[3] P. Sugiartawan et al., "Prediksi Data Time Series Multi Variabel Sliding Windows Menggunakan Model Hybrid Self Organizing Map ( Som ) Dengan Elman Recurrent Neural Network," 2016.

[4] P. Sugiartawan and I. G. S. Arta, "Peramalan Tingkat Kunjungan Wisatawan dengan Metode Average Based Fuzzy Time Series dan Markov Chain Model di Sriphala Resort \& Hotel," 2015.

[5] R. Boné and H. Cardot, "Advanced Methods for Time Series Prediction Using Recurrent Neural Networks," Recurr. Neural Networks Temporal Data ..., no. 1, 2011.

[6] Y. K. Y. Kong, Y. S. Y. Shi, and J. Y. J. Yuan, "Prediction Method of Time Series Data Stream Based on Wavelet Transform and Least Squares Support Vector Machine," 2008 Fourth Int. Conf. Nat. Comput., vol. 2, pp. 120-124, 2008.

[7] P. Sugiartawan, S. Hartati, and A. Musdholifah, "Prediction of Multivariat Time Series Data Using Fully Re- current Neural Network,", 2017, pp. 2-5.

[8] D. Hatidja, "Penerpan model Arima untuk memprediksi harga saham PT.Telkom Tbk," Progr. Stud. Mat. FMIPA Univ. Sam Ratulangi,manado, 2011.

[9] M. Aminudin, "Peramalan Cuaca Kota Surabaya Tahun 2011 Menggunakan Metode Moving Average dan Klasifikasi Naive Bayes," Surabaya, 2011.

[10] B. T. Ong, K. Sugiura, and K. Zettsu, "Dynamic pre-training of Deep Recurrent Neural Networks for predicting environmental monitoring data," Proc. - 2014 IEEE Int. Conf. Big Data, IEEE Big Data 2014, pp. 760-765, 2015.

[11] Y. Sun et al., "Research on Short-term Module Temperature Prediction Model Based on BP Neural Network for Photovoltaic Power Forecasting," 2015.

[12] K. Kuna, "Time Series Prediction using Neural Networks," p. 47, 2015.

[13] S. Assauri, Teknik \& Metode Peramalan. Jakarta: Fakultas Ekonomi Universitas Indonesia, 1984.

[14] N. Susanti, "Penerapan Model Neural Network Backpropagation untuk Prediksi Harga Ayam," Semin. Nas. Teknol. Ind. dan Inform., pp. 325-332, 2014.

[15] S. G. Rabiha and S. Santosa, "Prediksi Data Arus Lalu Lintas Jangka Pendek Menggunakan Optimasi Neural Network Berbasis Genetik Algorithm," Teknol. Inf., vol. 9, no. Prediksi arus lalu lintas, pp. 54-61, 2013.

[16] S. Husnan, Dasar-Dasar Teori Portfolio, 2nd ed. Yogyakarta: Percetakan MP YKPN, 1994.

[17] G. Indriyo, Manajemen Pemasaran, 2nd ed. Yogyakarta: BPFE, 2000.

JSIKTI Vol. 1, No. 2, December 2018: 87 - 96 